\title{
ЦУКРОВА ЗАЛЕЖНІСТЬ В ДІТЕЙ. ПРИЧИНИ ВИНИКНЕННЯ ТА СПОСОБИ ПОДОЛАННЯ
}

\author{
К. О. Надточий \\ ДВНЗ «Тернопільський державний медичний університет \\ імені І. Я. Горбачевського МОЗ Украӥни»
}

Стаття присвячена проблемі виникнення цукрової залежності та ії впливу на фізичне та психічне здоров’я людини, і дитини зокрема.

\section{SUGAR ADDICTION IN CHILDREN. GENESIS AND THE METHODS OF OVERCOMING}

\author{
K. O. Nadtochiy
}

\section{Horbachevsky Ternopil State Medical University}

The article is dedicated to the problem of the sugar addiction origins and its impact to physical and psychological health of a man and a child in particular.

Вступ. Раціональне харчування є важливою умовою формування здоров'я, гармонійного фізичного та нервово-психічного розвитку дітей різного віку. Цукрова залежність на сьогодні $є$ однією з найважливіших і найпоширеніших видів залежності на планеті. Вона наявна у багатьох дітей та підлітків, і, як наслідок, стосується мільйонів дорослих. Часто люди просто не помічають їі, адже вона $\epsilon$ такою соціально прийнятною. Однак вона призводить до таких тяжких захворювань, як карієс, ожиріння, остеопороз, рак, метаболічний синдром, мікроваскулярна стенокардія (так званий синдром X) i, врешті, до цукрового діабету. І в цій статті ми розглянемо загальну адиктивну поведінку, спричинену цукровим навантаженням на людський організм [1, 2].

Основна частина. Що ж таке залежність? Залежність - це взаємозв'язок, який з'являється коли ми здійснюємо заходи задля припинення негативного відчуття або симптомів. Після цього людина почуває себе краще, але такі заходи або речовини викликають у неї різні дисфункції в організмі. Це, в свою чергу, посилює залежність як спосіб полегшити дисфункцію, i розвивається порочне коло, при якому виникає потреба все в більшій кількості таких адиктивних речовин або адиктивної поведінки.

Причини цукрової залежності можуть бути фізичного та психологічного характеру.

(с) К. О. Надточий, 2018

\section{Причини фізичної чукрової залежності}

1. Дефіцит мінералів та поживних речовин.

Нестача цинку. В процесі утворення інсуліну необхідна досить велика кількість цинку, який також і подовжує дію інсуліну, аби вона не призупинялася. Ситуація на сьогодні така, що у більшості людей наявний дефіцит цинку, а також токсичний рівень міді, заліза, свинцю, ртуті й кадмію, які можуть заміщувати цинк у молекулі інсуліну, роблячи ї̈ легкою до руйнування. Таким чином, від нестачі цинку виникає інсулінорезистентність, що призводить до постійно підвищеного рівня глюкози в крові.

Хром. Він необхідний для контакту молекул інсуліну з мембранами клітин у процесі транспортування глюкози, і його нестача призводить до порушення цього процесу. Дефіцит хрому є досить поширеним як серед дітей, так і серед дорослого населення.

Вітаміни групи В також відіграють важливу роль в метаболізмі інсуліну. Деякі з них необхідні на різних рівнях метаболізму для того, щоби інсулін функціонував правильно. Дефіцит вітамінів групи В також широко поширене явище, особливо у вегетаріанських дієтах.

Магній також залучений до метаболізму інсуліну. Він необхідний для генерації ензиму, який бере участь у продукції інсуліну. Магній є критичним також і для інших ензимів [2, 3].

2. Токсичні метали. Такі токсичні елементи, як кадмій, свинець, ртуть, хлор, фториди та мідь можуть блокува- 
ти будь-який етап у циклі енергоутворення методом заміщення одного з основних компонентів, і таким чином, порушувати процес перетворення глюкози.

3. Стан надниркових залоз. Однією з функцій надниркових залоз $є$ регулювання та підтримка рівня глюкози в крові через глюкокортикоїдні гормони кортизол, кортизон. При недостатній активності надниркових залоз, рівень цукру в крові буде мати тенденцію до зниження. У результаті, клітинам буде доступна завжди менша кількість глюкози, ніж потрібно, і залежність від зовнішнього насичення цукром буде невідворотною.

4. Діабет та гіпоглікемія. Як відомо, при діабеті спостерігають високий рівень цукру у крові. Водночас, рівень цукру в клітинах перебуває на низькому рівні, і для процесів енергоутворення його не вистачає, що спричиняє залежність від зовнішніх джерел глюкози.

При гіпоглікемії можна спостерігати схожу ситуацію. Гіпоглікемія означає низький цукор у крові. Більше того, навіть якщо рівень цукру в крові перебуває в межах норми, клітини можуть страждати від нестачі глюкози, що також посилює цукрову залежність.

5. Порушення мікробіоти людини. Ще одна з можливих причин цукрової залежності - порушення мікробіоти дріжджоподібним грибком. Часто про наявність такої флори сигналізує постійна потреба людини в цукрі у будь-якому вигляді. Адже цукор є природним поживним середовищем для дріжджоподібних грибків, і якщо його рівень знижується, грибок гине.

Деякі види грибків здатні брати участь у синтезі алкоголеподібних хімічних речовин, які спричиняють у людини стан легкого сп'яніння, покращують настрій. Ця невелика кількість алкоголю зменшує такі відчуття, як депресія, тривожність, гнів тощо. Коли рівень цукру знижується, і грибок починає гинути, різко знижується і рівень алкоголю, що виділяв грибок. Як наслідок, людина починає почувати себе пригнічено, неспокійно, або бути дратівливою. Такі стани дуже швидко викликають звикання до солодкого, особливо коли людина не розуміє, чому має такі тяжкі симптоми, якщо перестає його споживати.

6. Незбалансована швидкість окиснення. Незбалансована швидкість окиснення означає знижену енергоефективність використання цукру. Ця причина цукрової залежності вже не пов'язана з метаболізмом глюкози як попередні, але скоріше є сумарним результатом усіх попередніх процесів. При дисфункції організму порушуються процеси окиснення та утворення енергії. У результаті, людина недоотримує необхідну енергію, і почуває себе апатично, депресивно. Тут і з'являється тенденція до переїдання цукру та їжі, щоби підняти рівень швидкості окиснення $[2,3]$.

У деяких випадках, навпаки, швидкість окиснення перебуває на рівні вищому, ніж нормальний. У результаті, людина швидко витрачає свої запаси глікогену в печінці й м'язах. І коли це трапляється, приходить залежність від зовнішнього надходження цукру до організму, що врешті-решт дає старт багатьом захворюванням метаболічного характеру, фізичним та психічним порушенням.

На жаль, цей перелік фізичних причин виникнення цукрової залежності ще не закінчується, а на практиці дуже часто поєднується з психологічними чинниками.

\section{Психологічні причини цукрової залежності}

Відомо, що споживання солодощів зменшує прояви агресії, злості, полегшує відчуття страху, тривоги, нудьги, самотності, депресії, фрустрації.

Ключовий орган, який формує психологічну залежність, це мозок, тому що споживання цукру стимулює бета-ендорфінові рецептори і дофамінову систему центру задоволення головного мозку. При споживанні солодощів, рівень цукру в крові швидко підвищується, після чого так само швидко падає. Причина зниження в тому, що у відповідь на цукор виробляється інсулін, який швидко перетворює глюкозу. Після різкого зниження глюкози, центр задоволення мозку більше не активується, мозок сприймає це як стрес, і у відповідь виділяється гормон адреналін, який надсилає сигнал мозку знову підвищити рівень цукру. Ми з'їдаємо щось солодке, рівень цукру знову підвищується, і все повторюється. Такі постійні процеси підвищення і зниження рівня цукру відображаються на психічному стані людини, а особливо дитини, як постійні зміни настрою, а викиди адреналіну можуть призвести до занепокоєння, тривожності та навіть нападів паніки.

У дітей психологічна залежність від солодкого має більш тяжкий перебіг та важче піддається лікуванню, ніж у дорослих, адже діти, маючи незрілу психіку, не усвідомлюють свій психологічний стан, і так само не усвідомлюють необхідність та шляхи свідомого виходу з нього. Дитячий мозок сприймає кореляцію між підвищенням рівня цукру в організмі й покращенням емоційного стану після цього, прагне задовольнити його дефіцит будь-яким способом. Тому відповідальність за залежність дітей від солодкого лежить цілком на дорослих.

Психологічний аспект виникнення залежності часто має коріння в минулому людини, зокрема в 
дитинстві. Наприклад, ваша мати, ваш дитячий стоматолог тощо давав вам цукерки у винагороду за гарну поведінку. Ця модель призводить до ситуації, що кожен раз, коли ця, вже доросла, людина їсть щось солодке, у неї або в нього виникає стійка асоціація, що «я - хороший». Це означає, що споживання солодкого стає емоційним тригером, який все більше поглиблює залежність. Більшість батьків не усвідомлює як цією системою солодкої винагороди прививає своїй дитині проблеми зі здоров'ям у майбутньому [2].

Найдієвішим способом подолати цукрову залежність $є$ збалансоване харчування:

- Повинно бути як мінімум 4 прийоми їжі на день для підтримання нормального рівня цукру в крові. Необхідно завжди дотримуватися 4-годинної перерви між прийомами їжі. Будь-яке проміжне харчування не рекомендують. Переконайтеся, що їжа містить жир і протеїн [1].

• Необхідно культивувати здоровий спосібжиття, включаючи 8-годинний сон, час на відпочинок протягом дня та позитивне і конструктивне ставлення до себе.

- Необхідно позбутися усіх звичок, які підживлюють звикання до цукру. Потрібно уникати спокуси наскільки це можливо, та не тримати вдома солодке взагалі. Наприклад, людина може захотіти солодкого у стресовій ситуації, або якщо пропустила основний прийом їжі, або коли знесилена. Необхідно ідентифікувати, в які моменти виникає потяг до солодкого, і що можна зробити, щоби привести хімічний стан свого тіла в норму, тим самим знижуючи потяг до солодкого. Тут варто зауважити щодо споживання фруктів та фруктомістких соків. Насправді фрукти не є частиною дієт збалансованого харчування, тому не варто замінювати інші види цукру фруктозою. Фрукти - це в основному цукор і вода з декількома вітамінами та іншими фітонутрієнтами. Необхідно не піддаватися пропаганді, яка зображує фрукти як здорову їжу. Краще не споживати цукор ні в якому вигляді, особливо це стосується дітей. Але якщо його неможливо уникнути, то мед - єдина задовільна заміна цукру $[3,4]$.

- Приймання хрому допомагає зменшити потяг до солодкого. Для цієї мети рекомендують 600-800 мг піколінату хрому щодня.

- Не використовуйте підсолоджувачі, адже вони підтримують смак солодкого, і залежність не зникає. Багато людей починають споживати штучні підсолоджувачі, думаючи, що так вони уникають проблеми з цукровою залежністю. Це не лише не $є$ правдою, а й в окремих випадках може погіршити ситуацію [2].
На сьогодні, кількість цукру, яку ми щоденно споживаємо, згідно з нашими дієтами, є набагато більшою за норму. У звітах ВООЗ наголошується, що кількість споживання цукру необхідно скорочувати до 5 \% від усього споживання енергії. Що є еквівалентом 7 чайним ложкам/кубикам, або 30 г цукру на день. Рекомендація для дітей складає 24 г для дітей віком 5-11 років і 19 г - для дітей 4-6 років. Цей $5 \%$ ліміт знаходиться нижче, ніж поточний рівень споживання цукру дітьми віком 1,5-3 роки, що складає 11,9\%, рівень споживання цукру дітьми 4-10 років 14,7 \% та 15,6 \% - дітьми віком 11-18 років. Також вважається, що прив'язка до $5 \%$ рекомендованого споживання цукру допоможе стримати зростання рівня ожиріння [5].

У 2017 р. в Україні Міністерство охорони здоров'я своїм наказом затвердило нові норми харчування. Головна відмінність - зменшена калорійність харчування для дітей віком 3-17 років та дорослих, а також зменшена вага вуглеводів [6].

Висновки. Звичка до цукру зазвичай починається в дитячому віці, але насправді, вона дедалі частіше стає вродженою. Сьогодні деякі діти народжуються $з$ нестачею життєвого резерву таких лужних металів, як $\mathrm{Zn}, \mathrm{Cr}$ та Mg. Ці діти можуть бути народжені зі схильністю до цукрової залежності. Залежність також може розвиватися рано через недбале ставлення батьків, які думають, що їхні діти просто люблять солодке, аж доки це не переростає у звичку.

Неконтрольоване використання антибіотиків у педіатричній практиці також може стати причиною порушення толерантності до глюкози, що тісно пов'язано з імунологічною реактивністю дитячого організму. Так, дослідження доводять, що цукор знижує імунітет в 17 разів, і чим більше цукру в крові, тим нижче захисні сили організму [7].

Також варто наголосити на державному регулюванні харчових виробництв. Більшість їжі, яка продається як «дитяча», задля збільшення смакової привабливості і, відповідно, попиту, містить додатковий цукор. Це становище $є$ ганебним і неприйнятним, адже «підсаджує» дітей на довічні проблеми зі здоров'ям та безпорадність.

Результатом цукрової залежності у дітей є дефіцит уваги, проблеми з навчанням, аутизм, гіперактивність, інфекції, пухлини мозку, інсульт та цілий ряд інших порушень. При дорослішанні сюди додаються депресія, обсесивно-компульсивний синдром, маніакально-депресивні та біполярні порушення, раптова агресія тощо [3, 7]. 
Варто пам'ятати, що навіть маленька залежність від цукру в дитинстві створює передумови до проблем

\section{СПИСОК ЛІТЕРАТУРИ}

1. Дієтологія / за ред. Н. В. Харченко, Г. А. Анохіної. - К. : Меридіан, 2012. - 526 с.

2. Sugar addiction. Lawrence Wilson, May 2016, L.D. Wilson Consultants, Inc., URL: <https://www.drlwilson.com/articles/ SUGAR\%20ADDICTION.htm>, [Acc. May 2016].

3. Relationship between added sugars consumption and chronic disease risk factors: Current understanding., J. Rippe, T. Angelopoulos. - Mode access : <https://www.ncbi.nlm.nih. gov/pmc/articles/PMC5133084/>, [Acc. Nov 4 2016].

4. Potential role of sugar (fructose) in epidemic of hypertension, obesity and metabolic syndrome, diabetes, kidney disease, cardiovascular disease / R. Johnson, M. Segal, Y. Sautin [et al.] // American Journal of Clinical Nutrition. - 2017. - здоров'я у дорослому віці, які скорочують людське життя.

Mode access : <http://ajcn.nutrition.org/content/86/4/899. full>. [Acc. 27th Jan 2015].

5. World Health Organisation, 2015. Obesity and Overweight. - Mode access : <http://www.who.int/mediacentre/ factsheets/fs311/en/>. [Acc.27th Jan 2015].

6. Про затвердження норм фізіологічних потреб населення України в основних харчових речовинах і енергії [Електронний ресурс] : наказ від 03.09.2017 р. № 1073. Міністерство охорони здоров'я України. - Режим доступу : <http://zakon2.rada.gov.ua/laws/show/z1206-17>

7. Jeavans C. How much sugar do we eat? BBC News / C. Jeavans. - Mode access : <http://www.bbc.co.uk/news/ health-27941325>.

Отримано 09.08.18 